\title{
Ratio of $\beta$-amyloid protein (A $\beta)$ and Tau predicts the postoperative cognitive dysfunction on patients undergoing total hip/knee replacement surgery
}

\author{
ZHIPENG WU, MEI ZHANG, ZHENHONG ZHANG, WEI DONG, QINGBEN WANG and JUAN REN \\ Department of Anesthesiology, People's Hospital of Shouguang, \\ Shouguang, Weifang, Shandong 262700, P.R. China
}

Received May 29, 2017; Accepted September 22, 2017

DOI: 10.3892/etm.2017.5480

\begin{abstract}
A} \beta)$ and Tau proteins are biomarkers of Alzheimer's disease neuropathogenesis. We hypothesized that they are also potential biomarkers for postoperative cognitive dysfunction (POCD). The present study was designed to evaluate the use of the $A \beta-42 /$ Tau ratio for the diagnosis of POCD in patients undergoing hip/knee replacement surgery. A total of 80 patients who underwent total hip/knee replacement surgery were grouped into POCD or non-POCD patients at 7 days, 1 and 3 months after surgery, according to a z-score recommended by the international study of POCD. Cerebrospinal fluid samples were collected prior to surgery and the concentration of $A \beta-42$ and Tau protein were detected. The ratio of $A \beta-42 /$ Tau was compared between the two groups at different time points. The patients completed the whole battery of neuropsychological tests following surgery. The POCD occurrence rates at 7 days, 1 and 3 months were 40,25 and $15 \%$, respectively. The $A \beta-42 /$ Tau ratios were much lower in the POCD group than those in the non-POCD group at 7 days $(1.7 \pm 0.4$ vs. $2.6 \pm 0.3), 1$ month

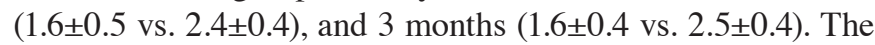
sensitivity and specificity for diagnosis of POCD as indicated by the ratios, at the three time points, were 91.7 vs. $81.2 \%$, 86.7 vs. $70 \%$, and 88 vs. $75.5 \%$, respectively. The results show the incidence of POCD of patients aged at least 65 years who have undergone hip or knee fracture surgery gradually decrease as more patients recover. However, the $A \beta-42 /$ Tau ratio can be used in forecasting the occurrence of POCD elderly patients.
\end{abstract}

\section{Introduction}

Postoperative cognitive dysfunction (POCD) is a cognitive performance deterioration occurring mainly after high-risk

Correspondence to: Dr Mei Zhang, Department of Anesthesiology, People's Hospital of Shouguang, 1233 Jiankang Street, Shouguang, Weifang, Shandong 262700, P.R. China

E-mail: shouguangwuzhipeng@163.com

Key words: postoperative cognitive dysfunction, $\beta$-amyloid protein, Tau, risk factor, total hip/knee replacement surgery surgery (or anesthesia). It is characterized by dysfunctions in mental activities, personality, interpersonal communication and cognitive competence. Patients with POCD usually complain of memory decline, and poor concentration and information processing ability (1). POCD is reversible in most patients, but a permanent cognitive impairment can sometimes ensue. Prolonged POCD increases the risk of dementia, and is associated with the development of Alzheimer's disease (AD) $(2,3)$. Therefore, it is of great importance to diagnosis POCD as early as possible; nevertheless, the pathogenesis of POCD is not clearly understood. It has been reported that the patients' age, education level, intelligence and genetics, as well as any underlying conditions, intraoperative factors and anesthesia may all be risk factors for POCD (4). For example, elder patients, especially those older than 65, are more susceptible to POCD than younger patients (5). Animal studies have shown that some anesthetic drugs impair the metabolism of acute phase proteins, inducing $\beta$-amyloid proteins $(A \beta)$ aggregation and plaque deposition in rats, which significantly damage their memory and spatial learning ability $(6,7)$. During surgery, reduced partial pressure of $\mathrm{CO}_{2}$ caused by hyperventilation has also been reported to be associated with a decrease of cerebral perfusion, thereby impairing the patient's cognitive ability (8).

The frequency of POCD is also associated with different invasive surgeries. Surgical invasion causes increased levels of inflammatory cytokines in the peripheral and central nervous system, which alter cognitive function by injuring the hippocampus (9). Previously, an increasing number of inflammatory cytokines have been recognized to affect the hippocampus-related cognitive function $(10,11)$. Nevertheless, the neuropathogenesis remains unclear, and biomarkers for the risk of POCD are not clearly determined.

A $\beta$, including 40 and 42 , are components of AD senile plaques. Tau is a microtubule-associated protein in neurons, which is essential for microtubule formation and structural stability (12). Both proteins have been reported to play roles in $\mathrm{AD}$ neuropathogenesis, therefore, it is possible that they may be effective biomarkers of POCD in postoperative patients.

Patients undergoing hip-replacement surgery are susceptible to POCD (11). In the present study, we selected older patients, who underwent total hip/knee replacement surgery, 
and detected the $A \beta-42$ and Tau levels in cerebrospinal fluid (CSF) before and after surgery, to analyze the diagnostic value of $A \beta-42 /$ Tau ratio on POCD occurrence. The results of our study provide a theoretical basis for the clinical diagnosis of POCD.

\section{Materials and methods}

Subjects. The Ethics Committee of People's Hospital of Shouguang (Shandong, China) approved the study. Eligible patients signed informed consent forms. A total of 80 patients (aged from 65 to 85 years) in American Standards Association (ASA), class II-III, who received total hip arthroplasty (THR) or total knee replacement (TKR) in our hospital, from October, 2014 to December, 2016 were enrolled in the present study. Patients presenting with preoperative mini-mental state examination (MMSE) scores $<24$, with a history of neurological or psychiatric disease (Alzheimer, stroke or psychological disease), with severe liver/renal dysfunction, with serious visual or hearing disturbances, those unable to communicate, speak or read, or were dependent on psychoactive drugs or alcohol, were excluded from the study. The WAIS (Wechsler Adult Intelligence Scale) (12) as well as the WBIS (Wechsler-Bellevue scale) (13) were used for neuropsychology tests before and after surgery. The incidence of POCD was evaluated by the z-score method. Patients were classified into POCD and non-POCD groups according to the cognitive condition. A group of 80 healthy volunteers aged $65-85$ years were recruited in our study as the control group.

Anesthesia management. The patients received standard anesthesia. Once in the operating room, the arterial blood pressure, electrocardiogram and $\mathrm{SPO}_{2}$ (saturation of pulse oximetry) were monitored. The patients were placed in a lateral position for combined spinal-epidural anesthesia. CSF was collected from each patient after subarachnoid puncture and stored at $-80^{\circ} \mathrm{C}$ for subsequent protein measurements. Anesthesia was induced with $0.75 \%$ ropivacaine hydrochloride ( $2 \mathrm{ml}$; AstraZeneca AB, Sodertalje, Sweden) in a $10 \%$ glucose injection $(0.5 \mathrm{ml})+\mathrm{CSF}(0.5 \mathrm{ml})$. After catheterization with a $4 \mathrm{~cm}$ epidural guiding tube, the patients were provided oxygen inspiration through mask $(2 \mathrm{l} / \mathrm{min})$. The systolic pressure was controlled and maintained $>100 \mathrm{mmHg}(5-10 \mathrm{mg}$ ephedrine; Hong Hui Pharmaceutical Co., Ltd., Zhengzhou, China) were injected intravenously if the blood pressure decreased $>30 \%$ of the basal value). The patients underwent THR or TKR during anesthesia and conventional perioperative care with analgesia as needed.

Neuropsychology test. The patients underwent neuropsychological tests prior to surgery, and then 7 days, 1 and 3 months after surgery. The test items included several different areas. To evaluate summation the subjects were required to continuously add the same number (3 or 4) from 1 to 49. The time spent in total, the errors and missing numbers were recorded to evaluate the subject's attention. The evaluation of visual reproduction included a visual learning and memory test requiring the subjects to recall and draw 3 images they were shown. The digit span is a test requiring subjects to repeat a group of digits forward, and then backwards. To
Table I. General characteristics of patients.

\begin{tabular}{lcc}
\hline Items & $\begin{array}{c}\text { Normal control } \\
(\mathrm{n}=80)\end{array}$ & $\begin{array}{c}\text { Patients } \\
(\mathrm{n}=80)\end{array}$ \\
\hline Age (mean $\pm \mathrm{SD}$, years $)$ & $73.6 \pm 5.8$ & $74.5 \pm 4.8$ \\
Weight (mean $\pm \mathrm{SD}, \mathrm{kg})$ & $57.2 \pm 5.1$ & $58.5 \pm 4.9$ \\
Height (mean $\pm \mathrm{SD}, \mathrm{cm})$ & $162.1 \pm 7.9$ & $163.2 \pm 8.0$ \\
ASA classification (II/III) & $22 / 58$ & $42 / 38$ \\
Years of education (years) & $9 \pm 3$ & $10 \pm 2$ \\
\hline
\end{tabular}

There are no significant differences between the two groups.

test language memory the subjects were given an associative learning test where they had to remember specifid terms they had heard in the allotted time. To evaluate processing speed, the subjects were given the digit symbol test, where they had to match numbers from 1 to 9 according to a given key within $90 \mathrm{sec}$. The last cognitive function test given was the ligature test, where the subjects connected a group of digits in order, and the time spent on the task was recorded.

Neuropsychology experts who had received professional training in a special room and at the same time performed all the above tests. Healthy individuals in the control group underwent the same cognitive assessments at the same time intervals as matching subjects in the patient's group.

Diagnosis of POCD. A z-score recommended by the International Study of Postoperative Cognitive Dysfunction (ISPOCD) was calculated for the diagnosis of POCD. First, the differences between the post- and pre-operative scores were calculated, then the test scores were divided by the standard deviation. If the $\mathrm{z}$-score was $>1.96$ for $>2$ times, the patient was classified as manifesting POCD $(5,14)$.

Concentration of $A \beta-42$ and Tau proteins. The levels of A $\beta-42$ and Tau proteins in CSF were measured using ELISA kits (Nanjing Jiancheng Bioengineering Research Institute, Nanjing, China) according to the manufacturer's instructions. Briefly, samples were assayed in triplicate (sample, standard, blank control) on ELISA plates coated with human anti-amyloid $\beta$ (anti-A $\beta 1-42$ ) or anti-Tau antibodies, and then positive samples were detected by horseradish peroxidase. The products were stained using tetramethyl benzidine for $15 \mathrm{~min}$. The reactions were analyzed on the microplate reader (RT-2,100 C; Shenzhen Keeptop Electronic Co., Ltd., Shenzhen, China) at $450 \mathrm{~nm}$.

Statistical analysis. Data were analyzed using SPSS 17.0 software (SPSS Inc. Chicago, IL, USA) software. Data were expressed as means \pm SD or percentage, and analyzed by t-test or $\chi^{2}$ test, respectively. The correlation between the A $\beta$-42/Tau proteins and $z$-scores were analyzed using the Pearson's correlation analysis. The cut-off value was determined by ROC (receiver operator characteristic) working curve. $\mathrm{P}<0.05$ was considered to indicate a statistically significant difference. 
Table II. General characteristics of patients in normal and patients groups (POCD and non-POCD group) on the 7th day post-operation.

\begin{tabular}{lcc}
\hline Items & POCD $(\mathrm{n}=32)$ & Non-POCD $(\mathrm{n}=48)$ \\
\hline Age $($ mean $\pm \mathrm{SD}$, ages $)$ & $74.3 \pm 5.2$ & $74.3 \pm 4.6$ \\
Weight $($ mean $\pm \mathrm{SD}, \mathrm{kg})$ & $59.9 \pm 5.1$ & $57.5 \pm 4.6$ \\
Height $($ mean $\pm \mathrm{SD}, \mathrm{cm})$ & $161.7 \pm 8.0$ & $162.5 \pm 8.2$ \\
ASA classification $(\mathrm{II} / \mathrm{III})$ & $10 / 22$ & $15 / 33$ \\
Years of education (mean $\pm \mathrm{SD})$ & $7 \pm 1.6$ & $8 \pm 2.3$ \\
Anesthesia time (mean $\pm \mathrm{SD}, \mathrm{min})$ & $132 \pm 22$ & $135 \pm 24$ \\
Time of operation (mean $\pm \mathrm{SD}$, min) & $93 \pm 16$ & $90 \pm 14$ \\
Bleeding volume during surgery (mean $\pm \mathrm{SD}, \mathrm{ml})$ & $207 \pm 94$ & $205 \pm 92$ \\
Ephedrine use $(\%)$ & 58 & 60 \\
\hline
\end{tabular}

There were no significant differences between the two groups; POCD, postoperative cognitive dysfunction; ASA, American Standards Association.

Table III. Results of neuropsychology test between the POCD and Non-POCD groups (mean $\pm \mathrm{SD}$ ) on the 7th day post-operation.

\begin{tabular}{llcc}
\hline Items & \multicolumn{1}{c}{ Time } & $\begin{array}{c}\text { POCD } \\
(\mathrm{n}=32)\end{array}$ & $\begin{array}{c}\text { Non-POCD } \\
(\mathrm{n}=48)\end{array}$ \\
\hline Summation & Pre-operative & $51 \pm 22$ & $68 \pm 18$ \\
& Post-operative & $23 \pm 37^{\mathrm{a}, \mathrm{c}}$ & $57 \pm 16 \mathrm{a}$ \\
Visual & Pre-operative & $9.2 \pm 1.7$ & $8.9 \pm 1.8$ \\
reproduction & Post-operative & $6.7 \pm 2.5^{\mathrm{b}}$ & $8.5 \pm 1.8$ \\
Associative & Pre-operative & $11.7 \pm 2.0$ & $11.5 \pm 3.8$ \\
learning & Post-operative & $8.9 \pm 2.5^{\mathrm{b}, \mathrm{c}}$ & $11.2 \pm 3.6$ \\
Digit & Pre-operative & $4.4 \pm 1.3$ & $4.8 \pm 0.9$ \\
span-forward & Post-operative & $4.6 \pm 1.5$ & $5.0 \pm 1.4$ \\
Digit & Pre-operative & $2.2 \pm 1.0$ & $3.6 \pm 0.9$ \\
span-backward & Post-operative & $1.7 \pm 1.4^{\mathrm{b}, \mathrm{c}}$ & $3.5 \pm 0.7$ \\
Digit & Pre-operative & $20 \pm 10$ & $20 \pm 5$ \\
symbol & Post-operative & $17 \pm 7$ & $20 \pm 5$ \\
Ligature & Pre-operative & $56 \pm 12$ & $56 \pm 13$ \\
& Post-operative & $56 \pm 9$ & $56 \pm 12$ \\
Total z-score & & $4.6 \pm 1.4^{\mathrm{c}}$ & $1.3 \pm 0.9$
\end{tabular}

${ }^{\mathrm{a}} \mathrm{P}<0.05 ;{ }^{\mathrm{b}} \mathrm{P}<0.01$, compared to the pre-operative time; ${ }^{\mathrm{c}} \mathrm{P}<0.01$, compared to the non-POCD; POCD, postoperative cognitive dysfunction

\section{Results}

General data between patients and normal controls, and between POCD and non-POCD. All 80 patients were successfully followed up, and the neuropsychological tests were completed on the 80 normal controls.

The percentages of patients experiencing POCD were 40 (32/80), $25(20 / 80)$ and 15\% (12/80) at 7 days, 1 and 3 months postoperatively, respectively. The details of general parameters for patients and normal controls are listed in Table I. There were no significant differences in terms of age, weight, height, sex, or years of education between the normal controls and the patients.
Neuropsychology test results on the 7th day after surgery. On the 7th day after surgery, there were 32 patients with POCD. For general data between patients presenting POCD $(n=32)$ and those not affected by it $(\mathrm{n}=48)$, no significant differences were found in terms of anesthesia time, operation duration, bleeding volume during surgery or amount of ephedrine used (Table II).

The neuropsychology tests (Table III) showed that the preoperative summation scores $(23 \pm 37$ vs. $51 \pm 22)$, visual reproduction scores $(6.7 \pm 2.5$ vs. $9.2 \pm 1.7)$, associative learning scores $(8.9 \pm 2.5$ vs. $11.7 \pm 2.0)$ and digit span-backward scores $(1.7 \pm 1.4$ vs. $2.2 \pm 1.0)$ were significantly reduced in the patients manifesting POCD after the operation $(\mathrm{P}<0.05)$. Compared to the patients not affected by POCD, those with POCD had lower scores in summation ( $23 \pm 37$ vs. $57 \pm 16)$, associative learning $(8.9 \pm 2.5$ vs. $11.2 \pm 3.6)$ and digit span-backward $(1.7 \pm 1.4$ vs. $3.5 \pm 0.7)$ after surgery.

Neuropsychology test results on the 1st month after surgery. One month after surgery, the number of patients suffering from POCD was reduced to 20. The general data between those affected and those not affected by POCD were not significantly different (Table IV).

Results of neuropsychology tests are listed in Table V. The preoperative summation scores $(37 \pm 31$ vs. $58 \pm 16)$, visual reproduction scores (7.2 \pm 2.4 vs. $9.4 \pm 1.4)$, associative learning scores $(9.1 \pm 2.4$ vs. $12.1 \pm 1.8)$ and digit span-backward scores $(1.8 \pm 1.4$ vs. $2.3 \pm 1.0)$ were significantly reduced after surgery $(\mathrm{P}<0.05)$. The scores of summation $(37 \pm 1$ vs. $51 \pm 24)$, associative learning (9.1 \pm .4 vs. $11.6 \pm 3.4)$, and digit span-backward $(1.8 \pm 1.4$ vs. $3.0 \pm 0.9)$ were lower in patients affected by POCD compared to those of patients not affected by it. Also, the ligature scores $(59 \pm 10$ vs. $55 \pm 12)$ were higher in POCD patients than in hose not affected by POCD.

Neuropsychology test results 3 months after surgery. Three months after surgery, 12 patients were reported to suffer from POCD. There were no significant differences in basic clinical data between those affected by POCD and those who were not affected (Table VI). 
Table IV. General characteristics of patients in normal control and patients group (POCD group and non-POCD) at 1 month post-operation.

\begin{tabular}{lcc}
\hline Items & $\begin{array}{r}\text { POCD } \\
(\mathrm{n}=20)\end{array}$ & $\begin{array}{c}\text { Non-POCD } \\
(\mathrm{n}=60)\end{array}$ \\
\hline Ages (mean $\pm \mathrm{SD}$, ages ) & $75.1 \pm 5.2$ & $74.6 \pm 5.1$ \\
Weight (mean $\pm \mathrm{SD}, \mathrm{kg})$ & $60.2 \pm 5.1$ & $59.4 \pm 4.5$ \\
Height (mean $\pm \mathrm{SD}, \mathrm{cm})$ & $162.3 \pm 8.4$ & $161.8 \pm 8.9$ \\
ASA classification (II/III) & $8 / 12$ & $16 / 44$ \\
Years of education (mean $\pm \mathrm{SD})$ & $8 \pm 2$ & $8 \pm 2$ \\
Anesthesia time (mean $\pm \mathrm{SD}, \mathrm{min})$ & $130 \pm 22$ & $132 \pm 24$ \\
Time of operation (mean $\pm \mathrm{SD}, \mathrm{min})$ & $95 \pm 16$ & $93 \pm 15$ \\
Bleeding volume & $205 \pm 94$ & $205 \pm 92$ \\
during surgery (mean $\pm \mathrm{SD}, \mathrm{ml})$ & & \\
Ephedrine use (\%) & 56 & 60 \\
\hline
\end{tabular}

There were no significant differences between the two groups; POCD, postoperative cognitive dysfunction; ASA, American Standards Association.

Table V. Results of the neuropsychology test between the POCD and non-POCD groups (mean $\pm \mathrm{SD}$ ) at 1 month post-operation.

\begin{tabular}{llcc}
\hline Items & \multicolumn{1}{c}{ Time } & $\begin{array}{c}\text { POCD } \\
(\mathrm{n}=12)\end{array}$ & $\begin{array}{c}\text { Non-POCD } \\
(\mathrm{n}=68)\end{array}$ \\
\hline Summation & Pre-operative & $58 \pm 16$ & $62 \pm 23$ \\
& Post-operative & $37 \pm 31^{\mathrm{a}, \mathrm{c}}$ & $51 \pm 24^{\mathrm{a}}$ \\
Visual & Pre-operative & $9.4 \pm 1.4$ & $8.9 \pm 1.9$ \\
reproduction & Post-operative & $7.2 \pm 2.4^{\mathrm{b}}$ & $8.4 \pm 2.2$ \\
Associative & Pre-operative & $12.1 \pm 1.8$ & $11.4 \pm 3.5$ \\
learning & Post-operative & $9.1 \pm 2.4^{\mathrm{b}, \mathrm{c}}$ & $11.6 \pm 3.4$ \\
Digit & Pre-operative & $4.7 \pm 1.2$ & $4.6 \pm 1.1$ \\
span-forward & Post-operative & $4.6 \pm 1.3$ & $4.7 \pm 1.3$ \\
Digit & Pre-operative & $2.3 \pm 1.0$ & $3.2 \pm 1.1$ \\
span-backward & Post-operative & $1.8 \pm 1.4^{\mathrm{b}, \mathrm{c}}$ & $3.0 \pm 0.9$ \\
Digit & Pre-operative & $21 \pm 9$ & $20 \pm 7$ \\
symbol & Post-operative & $21 \pm 7$ & $20 \pm 7$ \\
Ligature & Pre-operative & $58 \pm 11$ & $56 \pm 13$ \\
& Post-operative & $59 \pm 10^{\mathrm{c}}$ & $55 \pm 12$ \\
Total z-score & & $3.7 \pm 1.1^{\mathrm{c}}$ & $1.2 \pm 0.7$ \\
\hline
\end{tabular}

${ }^{\mathrm{a}} \mathrm{P}<0.05$; ${ }^{\mathrm{b}} \mathrm{P}<0.01$, compared to the pre-operative time; ${ }^{\mathrm{c}} \mathrm{P}<0.01$, compared to the non-POCD; POCD, postoperative cognitive dysfunction.

At 3 months following surgery, the scores of the preoperative summation ( $36 \pm 30$ vs. $60 \pm 17$ ), visual reproduction (7.1 \pm 2.4 vs. $9.5 \pm 1.6)$, associative learning $(9.0 \pm 2.4$ vs. $12.1 \pm 2.0)$ and digit span-backward ( $1.9 \pm 1.5$ vs. $2.4 \pm 1.0)$ were lower than those previous to the surgeries $(\mathrm{P}<0.05)$. The summation scores $(36 \pm 30$ vs. $52 \pm 24)$ and associative learning scores $(9.0 \pm 2.4$ vs. $11.5 \pm 3.4)$ were lower in the patients presenting
Table VI. General characteristics of patients in the normal control and patients group (POCD and non-POCD group) at 3 months post-operation.

\begin{tabular}{lcc}
\hline Items & $\begin{array}{c}\text { POCD } \\
(\mathrm{n}=20)\end{array}$ & $\begin{array}{c}\text { Non-POCD } \\
(\mathrm{n}=60)\end{array}$ \\
\hline Age (mean $\pm \mathrm{SD})$ & $75.7 \pm 5.2$ & $75.3 \pm 4.9$ \\
Weight (mean $\pm \mathrm{SD}, \mathrm{kg})$ & $61.8 \pm 5.2$ & $60.3 \pm 5.4$ \\
Height (mean $\pm \mathrm{SD}, \mathrm{cm})$ & $163.3 \pm 8.1$ & $162.1 \pm 8.7$ \\
ASA classification (II/III) & $4 / 8$ & $22 / 46$ \\
Years of education (mean $\pm \mathrm{SD})$ & $8 \pm 2$ & $8 \pm 2$ \\
Anesthesia time (mean $\pm \mathrm{SD}, \mathrm{min})$ & $135 \pm 24$ & $132 \pm 22$ \\
Time of operation (mean $\pm \mathrm{SD}, \mathrm{min})$ & $97 \pm 16$ & $95 \pm 16$ \\
Bleeding volume during surgery & $210 \pm 95$ & $207 \pm 92$ \\
(mean \pm SD, ml) & & \\
Ephedrine use $(\%)$ & 57 & 59 \\
\hline
\end{tabular}

There were no significant differences between the two groups; POCD, postoperative cognitive dysfunction; ASA, American Standards Association.

Table VII. Results of neuropsychology test between the POCD and non-POCD groups (mean $\pm \mathrm{SD}$ ) at 3 months post-operation.

\begin{tabular}{llcc}
\hline Items & \multicolumn{1}{c}{ Time } & $\begin{array}{c}\text { POCD } \\
(\mathrm{n}=32)\end{array}$ & $\begin{array}{c}\text { Non-POCD } \\
(\mathrm{n}=48)\end{array}$ \\
\hline Summation & Pre-operative & $60 \pm 17$ & $64 \pm 24$ \\
& Post-operative & $36 \pm 30^{\mathrm{a}, \mathrm{c}}$ & $52 \pm 24^{\mathrm{a}}$ \\
Visual & Pre-operative & $9.5 \pm 1.6$ & $8.9 \pm 2.0$ \\
reproduction & Post-operative & $7.1 \pm 2.4^{\mathrm{b}}$ & $8.5 \pm 2.2$ \\
Associative & Pre-operative & $12.1 \pm 2.0$ & $11.6 \pm 3.5$ \\
learning & Post-operative & $9.0 \pm 2.4^{\mathrm{b}, \mathrm{c}}$ & $11.5 \pm 3.4$ \\
Digit & Pre-operative & $4.6 \pm 1.2$ & $4.5 \pm 1.2$ \\
span-forward & Post-operative & $4.6 \pm 1.3$ & $4.7 \pm 1.3$ \\
Digit & Pre-operative & $2.4 \pm 1.0$ & $3.2 \pm 1.0$ \\
span-backward & Post-operative & $1.9 \pm 1.5^{\mathrm{b}}$ & $3.1 \pm 1.0$ \\
Digit & Pre-operative & $22 \pm 9$ & $21 \pm 7$ \\
symbol & Post-operative & $21 \pm 8$ & $20 \pm 7$ \\
Ligature & Pre-operative & $60 \pm 11$ & $56 \pm 12$ \\
& Post-operative & $58 \pm 10^{\mathrm{c}}$ & $54 \pm 12$ \\
Total score & & $3.5 \pm 1.1^{\mathrm{c}}$ & $1.1 \pm 0.6$ \\
\hline
\end{tabular}

${ }^{\mathrm{a}} \mathrm{P}<0.05$; ${ }^{\mathrm{b}} \mathrm{P}<0.01$, compared to the pre-operative time; ${ }^{\mathrm{c}} \mathrm{P}<0.01$, compared to the non-POCD. POCD, postoperative cognitive dysfunction.

POCD and the ligature score $(58 \pm 10$ vs. $54 \pm 12)$ was higher in these patients (Table VII).

Concentrations of $A \beta-42$ and Tau proteins after surgery. The concentration of $A \beta-42$ and Tau proteins in the CSF samples were detected to evaluate nervous system injury after surgery. The results showed that at 7 days, 1 and 

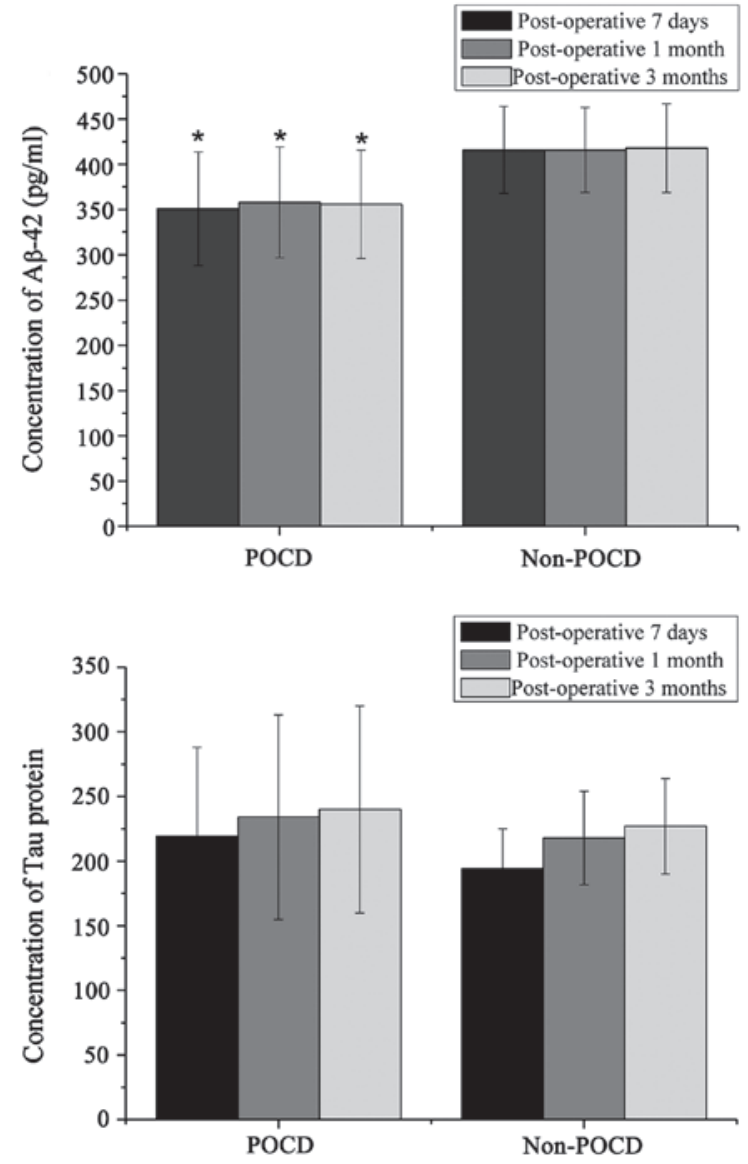

Figure 1. Concentrations of $A \beta-42$ and Tau proteins after surgery.

3 months after surgery, the $A \beta-42$ proteins were significantly reduced in the samples of those affected by POCD (Fig. 1). However, the Tau proteins did not seem to be affected, and there were no significant differences between the two groups of patients.

ROC curve presents the diagnostic effect of $A \beta-42$ and Tau proteins on POCD occurrence after surgery (Fig. 2). The ratios of $A \beta-42$ and Tau in patients affected by POCD were much lower than those of unaffected patients $(\mathrm{P}<0.05)$, and it they negatively correlated with the $\mathrm{z}$-scores $(\mathrm{r},-0.681, \mathrm{P}<0.05$; $r,-0.643, \mathrm{P}<0.05 ; \mathrm{r},-0.620, \mathrm{P}<0.05$, respectively for post-operative 7 days, 1 and 3 months). The sensitivity and specificity of the ratios for POCD occurrence were 91.7 and 81.2, 86.7 and $70.0,88.0$ and $75.5 \%$ for 7 days, 1 month, and 3 months, respectively, after surgery time points.

\section{Discussion}

The pathogenesis of POCD is currently unclear. Thus, the identification of biomarkers for POCD has drawn much attention by neurologists. Previous studies have confirmed the diagnostic value of $\mathrm{A} \beta$ and Tau proteins for $\mathrm{AD}(15,16)$. It is thought that POCD shares similar neuropathological mechanisms with $\mathrm{AD}$ (17). Thus, $\mathrm{A} \beta$ and Tau proteins are hypothesized to be similarly useful for the diagnosis of POCD.

Several recent studies have evaluated the diagnostic efficacy of CSF A $\beta$ and Tau proteins for POCD after different

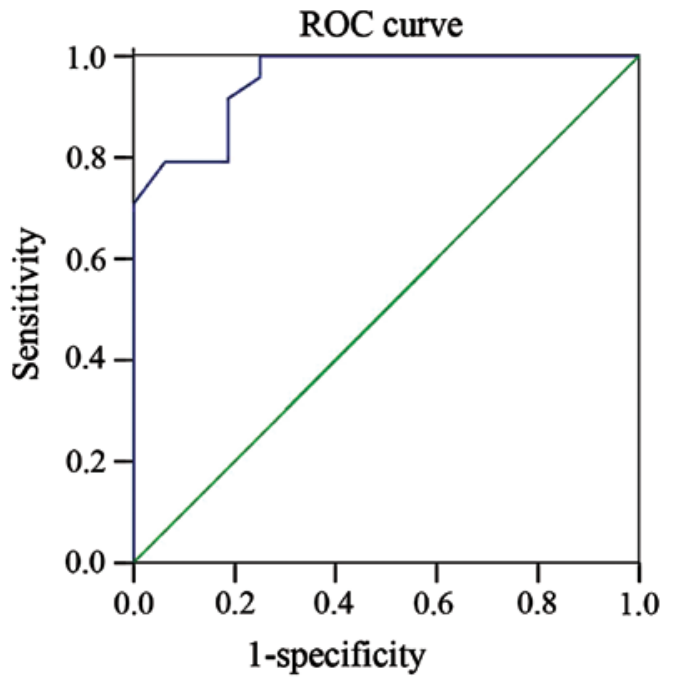

Figure 2. ROC curves of $A \beta-42$ and Tau ratio for diagnosis of post-operative POCD.

procedures. For example, Evered et al found that protein levels of $A \beta 42$ and 40 in the blood are associated with the cognitive dysfunction after cardiac surgery (18). Two Chinese studies have also suggested that the patients undergoing hip/knee replacements with low CSF A $\beta 42$ levels had high risk of cognitive dysfunction $(11,19)$. However, the authors of the two studies did not use the POCD diagnostic criteria recommended by the International Society of Preventive and Community Dentistry (ISPCD) group. Until recently, the ISPCD diagnostic criteria for POCD had not been used extensively in China. Our study evaluated the correlation between the CSF A $\beta 42 /$ Tau ratio and the scores of international cognitive tests. The results show that the percentage of patients who develop POCD after hip/knee replacement were 40,25 and $15 \%$ at 7 days, 1 and 3 months postoperatively, respectively. Additionally, in agreement with the findings from previous studies, our study has also demonstrated the diagnostic effect of the $A \beta 42 /$ Tau ratio on POCD patients.

The evaluation of the patient's neuropsychology is essential for the diagnosis of POCD. There are many criteria to take into account for detection of neuropsychological abnormalities. The ISPOCD recently recommended a battery of neuropsychology tests for assessing patient's mental states. This includes several tests such as the stroop color-word, the visual language learning and the alphabet number coding test. The WAIS and WBIS tests used for this study are also included in the ISPOCD recommendations. They are applicable to Chinese patients for evaluation of cognitive function with high sensitivity and specificity (20). However, the test methods are time-consuming, and therefore may not be well tolerated by patients. To prevent problems in this study, we used the MMSE preoperatively for preliminary screening.

It has been suggested that an inflammatory response may be associated with decline of neurocognition after anesthesia or surgery $(9,21,22)$. Previous studies have also shown that both anesthesia and surgery are associated with the $A \beta$ and Tau proteins in CSF $(23,24)$. A central cholinergic system of neurotransmitters can regulate memory, consciousness and learning of an individual (25). As members of ligand-gated 
cation channels, nicotinic acetylcholine receptors play key roles in the neurotransmitter system. In this context, the $\mathrm{A} \beta$ proteins are reported to have adverse effects on the synthesis and release of acetylcholine (26). It has been previously shown that overexpression of $\mathrm{A} \beta$ proteins profoundly damages an individual's learning memory and hippocampal volume (27).

The neuropathological characteristics for AD include the presence of extracellular plaques of $\mathrm{A} \beta$ peptides and neurofibrillary tangles formed by hyperphosphorylated Tau proteins $(16,28)$. Tau is a microtubule-associated protein and has 6 isoforms in humans. In pathological conditions such as craniocerebral injury, Tau proteins assemble and are hyperphosphorylated to form neurofibrillary tangles $(29,30)$. Reports have shown that under anesthesia of any kind a transient and reversible high phosphorylation of Tau protein is induced. However, Tau phosphorylation is probably associated with the lower temperature in the body caused by the anesthesia (31) and the content of Tau in CSF is not affected.

In this study, we chose the ratio of $A \beta-42 /$ Tau for evaluation of POCD risk for two reasons. First, A $\beta-42$ proteins are more liable to aggregate and deposit outside of cells, causing much more toxicity to neurons than $\mathrm{A} \beta-40$, and second, previous studies have demonstrated that the $A \beta-42 /$ Tau ratio is an important biomarker in the diagnosis of $\mathrm{AD}$. Moreover, the $\mathrm{A} \beta-42 / \mathrm{Tau}$ ratio is more sensitive for $\mathrm{AD}$ detection than $A \beta-42$ or Tau alone. Our results showed that there were significant differences in the ratios between the patients affected by POCD and those not affected at 7 days (sensitivity, 91.7 and specificity, 81.2\%), one month (sensitivity, 6.7 and specificity, 81.2\%) and 3 months (sensitivity, 86.7 and specificity, $70 \%$ ) after surgery. These results indicate that the ratio of $A \beta-42 /$ Tau can be used to predict the occurrence of POCD.

In conclusion, there are significant associations between the preoperative and postoperative $A \beta-42 /$ Tau ratio and cognition dysfunctions. The results of this study agree with other reported studies where the $\mathrm{A} \beta-42 / \mathrm{Tau}$ ratio is a potential biomarker for diagnosing POCD.

\section{References}

1. Monk TG and Price CC: Postoperative cognitive disorders. Curr Opin Crit Care 17: 376-381, 2011.

2. Vanderweyde T, Bednar MM, Forman SA and Wolozin B: Iatrogenic risk factors for Alzheimer's disease: Surgery and anesthesia. J Alzheimers Dis 22: 91-104, 2010.

3. Bittner EA, Yue Y and Xie Z: Brief review: Anesthetic neurotoxicity in the elderly, cognitive dysfunction and Alzheimer's disease. Can J Anaesth 58: 216-223, 2011.

4. Jungwirth B, Zieglgänsberger W, Kochs E and Rammes G: Anesthesia and postoperative cognitive dysfunction (POCD). Mini Rev Med Chem 9: 1568-1579, 2009

5. Canet J, Raeder J, Rasmussen LS, Enlund M, Kuipers HM, Hanning CD, Jolles J, Korttila K, Siersma VD, Dodds C, et al: ISPOCD2 investigators: Cognitive dysfunction after minor surgery in the elderly. Acta Anaesthesiol Scand 47: 1204-1210, 2003.

6. Culley DJ, Baxter MG, Yukhananov R and Crosby G: Long-term impairment of acquisition of a spatial memory task following isoflurane-nitrous oxide anesthesia in rats. Anesthesiology 100: 309-314, 2004

7. Eckenhoff RG, Johansson JS, Wei H, Carnini A, Kang B, Wei W, Pidikiti R, Keller JM and Eckenhoff MF: Inhaled anesthetic enhancement of amyloid-beta oligomerization and cytotoxicity. Anesthesiology 101: 703-709, 2004.
8. Gill M, Natoli MJ, Vacchiano C, MacLeod DB, Ikeda K, Qin M Pollock NW, Moon RE, Pieper C and Vann RD: Effects of elevated oxygen and carbon dioxide partial pressures on respiratory function and cognitive performance. J Appl Physiol 1985 117: 406-412, 2014.

9. Cibelli M,Fidalgo AR, Terrando N,MaD,Monaco C,Feldmann M, Takata M, Lever IJ, Nanchahal J, Fanselow MS, et al: Role of interleukin-1 $\beta$ in postoperative cognitive dysfunction. Ann Neurol 68: 360-368, 2010

10. McDonagh DL, Mathew JP, White WD, Phillips-Bute B, Laskowitz DT, Podgoreanu MV, Newman MF and Neurologic Outcome Research Group: Cognitive function after major noncardiac surgery, apolipoprotein E4 genotype, and biomarkers of brain injury. Anesthesiology 112: 852-859, 2010.

11. Ji MH, Yuan HM, Zhang GF, Li XM, Dong L, Li WY, Zhou ZQ and Yang JJ: Changes in plasma and cerebrospinal fluid biomarkers in aged patients with early postoperative cognitive dysfunction following total hip-replacement surgery. J Anesth 27: 236-242, 2013.

12. Guo T, Noble W and Hanger DP: Roles of tau protein in health and disease. Acta Neuropathol 133: 665-704, 2017.

13. Wechsler D: Wechsler Adult Intelligence Scale. 4th edition. Springer, pp3346-3346, 2008.

14. Lin R, Zhang F, Xue Q and Yu B: Accuracy of regional cerebral oxygen saturation in predicting postoperative cognitive dysfunction after total hip arthroplasty: Regional cerebral oxygen saturation predicts POCD. J Arthroplasty 28: 494-497, 2013.

15. Somers C, Struyfs H, Goossens J, Niemantsverdriet E, Luyckx J, De Roeck N, De Roeck E, De Vil B, Cras P, Martin JJ, et al: A decade of cerebrospinal fluid biomarkers for Alzheimer's disease in Belgium. J Alzheimers Dis 54: 383-395, 2016.

16. Weiner MW, Veitch DP, Aisen PS, Beckett LA, Cairns NJ, Green RC, Harvey D, Jack CR, Jagust W, Liu E, et al: Alzheimer's disease neuroimaging initiative: The Alzheimer's disease neuroimaging initiative: A review of papers published since its inception. Alzheimers Dement 8: 1-68, 2012.

17. Fodale V, Santamaria LB, Schifilliti D and Mandal PK: Anaesthetics and postoperative cognitive dysfunction: A pathological mechanism mimicking Alzheimer's disease. Anaesthesia 65: 388-395, 2010.

18. Evered LA, Silbert BS, Scott DA, Maruff P, Laughton KM, Volitakis I, Cowie T, Cherny RA, Masters CL and Li QX: Plasma amyloid beta42 and amyloid beta40 levels are associated with early cognitive dysfunction after cardiac surgery. Ann Thorac Surg 88: 1426-1432, 2009.

19. Xie Z, McAuliffe S, Swain CA, Ward SA, Crosby CA, Zheng H, Sherman J, Dong Y, Zhang Y, Sunder N, et al: Cerebrospinal fluid $\mathrm{a} \beta$ to Tau ratio and postoperative cognitive change. Ann Surg 258: 364-369, 2013.

20. Dai XY, Ryan JJ, Paolo AM and Harrington RG: Factor analysis of the mainland Chinese version of the Wechsler Adult Intelligence Scale. Int J Neurosci 55: 2-4, 1990.

21. McDonagh DL, Mathew JP, White WD, Phillips-Bute B, Laskowitz DT, Podgoreanu MV and Newman MF: Neurologic outcome research group: Cognitive function after major noncardiac surgery, apolipoprotein E4 genotype, and biomarkers of brain injury. Anesthesiology 112: 852-859, 2010.

22. Hudetz JA, Gandhi SD, Iqbal Z, Patterson KM and Pagel PS: Elevated postoperative inflammatory biomarkers are associated with short- and medium-term cognitive dysfunction after coronary artery surgery. J Anesth 25: 1-9, 2011

23. Tang JX, Baranov D, Hammond M, Shaw LM, Eckenhoff MF and Eckenhoff RG: Human Alzheimer and inflammation biomarkers after anesthesia and surgery. Anesthesiology 115: 727-732, 2011.

24. Palotás A, Reis HJ, Bogáts G, Babik B, Racsmány M, Engvau L, Kecskeméti E, Juhász A, Vieira LB, Teixeira AL, et al: Coronary artery bypass surgery provokes Alzheimer's disease-like changes in the cerebrospinal fluid. J Alzheimers Dis 21: 1153-1164, 2010.

25. Amenta F, Parnetti L, Gallai V and Wallin A: Treatment of cognitive dysfunction associated with Alzheimer's disease with cholinergic precursors. Ineffective treatments or inappropriate approaches? Mech Ageing Dev 122: 2025-2040, 2001.

26. Kar S, Slowikowski SP, Westaway D and Mount HT: Interactions between beta-amyloid and central cholinergic neurons: Implications for Alzheimer's disease. J Psychiatry Neurosci 29: 427-441, 2004

27. Weiss C, Venkatasubramanian PN, Aguado AS, Power JM, Tom BC, Li L, Chen KS, Disterhoft JF and Wyrwicz AM: Impaired eyeblink conditioning and decreased hippocampal volume in PDAPP V717F mice. Neurobiol Dis 11: 425-433, 2002. 
28. Trojanowski JQ, Vandeerstichele H, Korecka M, Clark CM, Aisen PS, Petersen RC, Blennow K, Soares H, Simon A, Lewczuk $\mathrm{P}$, et al: Alzheimer's disease neuroimaging initiative: Update on the biomarker core of the Alzheimer's disease neuroimaging initiative subjects. Alzheimers Dement 6: 230-238, 2010.

29. McKee AC, Cantu RC, Nowinski CJ, Hedley-Whyte ET, Gavett BE, Budson AE, Santini VE, Lee HS, Kubilus CA and Stern RA: Chronic traumatic encephalopathy in athletes: Progressive Tauopathy after repetitive head injury. J Neuropathol Exp Neurol 68: 709-735, 2009.

30. Ojo JO, Mouzon B, Greenberg MB, Bachmeier C, Mullan M and Crawford F: Repetitive mild traumatic brain injury augments Tau pathology and glial activation in aged hTau mice. J Neuropathol Exp Neurol 72: 137-151, 2013.
31. Kocherhans S, Madhusudan A, Doehner J, Breu KS, Nitsch RM, Fritschy JM, Knuesel I: Reduced Reellin expression accelerates amyloid-beta plaque formation and Tau pathology in transgenic Alzheimer's disease mice. J Neurosci 30: 9228, 2010.

c) (i)(9) This work is licensed under a Creative Commons Attribution-NonCommercial-NoDerivatives 4.0 International (CC BY-NC-ND 4.0) License. 